\title{
PENGARUH BAURAN PEMASARAN TERHADAP KEPUTUSAN PEMBELIAN ONLINE BUSANA MUSLIM DI INDUSTRI NANAD HIJAB CIBINONG BOGOR
}

\author{
${ }^{1)}$ Wawan Hari Subagyo, ${ }^{2)}$ Yulia Safitri \\ ${ }^{1)}$ Dosen Program Studi Manajemen, STIE Dewantara \\ Jl. Raya Pemda Bojong Depok Baru III, Karadenan, Cibinong, Bogor, Jawa Barat 16913, Indonesia \\ Email: wawan.hari@dewantara.ac.id \\ ${ }^{2)}$ Alumni Program Studi Manajemen, STIE Dewantara \\ J1. Raya Pemda Bojong Depok Baru III, Karadenan, Cibinong, Bogor, Jawa Barat 16913, Indonesia \\ Email: safit.safitri16@gmail.com
}

\begin{abstract}
Fashion muslim development in the country rapid progress. Because many women in awareness muslim clothed covered in accordance with what god, make and it has now become a muslim needs. This impact for the entrepreneur the clothing industry for a racing in creating innovation and producing muslim clothes. Research aims to understand the influence of, products, price, promotion and a partial and in simultaneous with the resolution of the purchase of products in the Nanad Hijab Industry. This type of research is causal research with quantitative methods. The population of this study includes consumers who buy Nanad Hijab products online through the Shopee application with a sample of 80 respondents. Methods of collecting data through questionnaires. The analysis used is the validity, reliability test, analysis linear regression multiple, the assumption classical, and the hypothesis. The results showed that Product Variables had a significant effect on the Muslim Muslim online purchasing decisions in the Nanad Hijab Cibinong Industry, Price Variables had a significant effect on the Muslim Muslim online purchase decision in the Nanad Hijab Cibinong Industry, Promotion Variables had a significant effect on Muslim fashion online purchasing decisions at the Nanad Hijab Industry Cibinong. The Marketing Mix jointly influences the decision to purchase Muslim fashion online at the Nanad Hijab Cibinong Industry.
\end{abstract}

Keywords: Product, Price, Promotion, Decision Purchase.

\begin{abstract}
ABSTRAK
Perkembangan fashion muslimah di tanah air mengalami kemajuan yang pesat. Dikarenakan banyaknya kesadaran wanita muslimah dalam berpakaian tertutup sesuai dengan syariat Islam, membuat busana muslim saat ini menjadi sebuah kebutuhan. Kondisi tersebut memberikan dampak bagi para pengusaha industri pakaian untuk berlomba dalam menciptakan inovasi dan memproduksi pakaian muslim. Penelitian ini bertujuan untuk mengetahui pengaruh produk, harga, promosi, dan tempat secara parsial dan simultan terhadap keputusan pembelian produk busana muslim pada Industri Nanad Hijab Cibinong Bogor. Jenis penelitian menggunakan metode kuantitatif kausalitas. Sampel penelitian ini meliputi konsumen yang membeli produk Nanad Hijab secara online melalui aplikasi Shopee sebanyak 80 responden. Teknik analisis data yang digunakan adalah analisa regresi linier berganda. Hasil penelitian menunjukkan bahwa Variabel produk, harga dan promosi secara parsial dan simultan berpengaruh signifikan terhadap keputusan pembelian online busana muslim di Industri Nanad Hijab Cibinong Bogor.
\end{abstract}

Kata kunci: Produk, Harga, Promosi, Keputusan Pembelian. 


\section{PENDAHULUAN}

\subsection{Latar Belakang}

Perkembangan fashion muslimah di tanah air mengalami kemajuan yang pesat. Saat ini kesadaran wanita muslimah dalam menggunakan pakaian tertutup sesuai dengan syariat Islam membuat permintaan terhadap busana muslim saat ini semakiin meningkat. Hal ini merupakan peluang bagi pelaku usaha busana muslim. Selain itu, terjadi pula persaingan yang ketat diantara para pelaku usaha bisnis ini sehingga pelaku bisnis busana muslim dituntut memiliki kemampuan dalam mengetahui keinginan dan kebutuhan para konsumen agar tertarik untuk menggunakan dan membeli produk pakaian muslim hasil produksinya. Untuk mengetahui perilaku konsumen, pelaku usaha perlu mempelajari perilaku konsumen dalam berbelanja. Saat ini penggunaan teknologi digital dapat membantu dan memaksimalkan para pelaku usaha bisnis dalam memahami reaksi perilaku konsumen terhadap suatu produk, sehingga para pelaku bisnis dapat dengan cermat memahami keinginan, selera maupun kebutuhan yang diminati konsumen. Salah satu penggunaan teknologi digital dalam pemasaran saat ini yang banyak diminati konsumen adalah penjualan secara online atau melalui sosial media karena selain memudahkan konsumen dalam membeli produk juga lebih efektif dan efisien.

Menurut Kotler (2009: 184), tahaptahap yang dilewati pembeli untuk mencapai keputusan pembelian melewati lima tahap, yaitu: pengenalan masalah, pencarian informasi, evaluasi alternatif, keputusan pembelian, dan tingkah laku pasca pembelian. Konsumen memerlukan suatu strategi tersendiri untuk mencapai sasaran tersebut dan terdapat beberapa faktor yang turut mempengaruhi, yaitu faktor eksternal dan internal. Faktor eksternal yaitu faktor yang berada di luar perusahaan, seperti: teknologi, keadaan ekonomi, peraturan pemerintah, dan lingkungan sosial budaya. Sedangkan faktor internal adalah variabel-variabel yang terdiri dari produk (product), harga (price) dan promosi (promotion)

Nanad hijab merupakan salah satu perusahaan home industri yang bergerak dalam bidang pembuatan busana muslim. Nanad hijab terkenal dengan produk yang memiliki kualitas yang baik dan harga yang terjangkau, sehingga diminati konsumen. Dikarenakan banyaknya konsumen yang lebih percaya untuk membeli produk yang sudah mempunyai merek seperti Rabbani, Zoya, Elzatta, dan merek lainnya membuat Nanad Hijab terus melakukan inovasi dengan mengutamakan kualitas dalam produknya. Laporan penjualan Nanad Hijab memperlihatkan volume penjualan yang mengalami fluktuasi. Hal tersebut dapat dilihat dari target dan realisasi penjualan pada tahun 2017 dan 2018 yaitu sebagai berikut.

\section{Tabel 1.1 Target dan Realisasi Penjualan Nanad Hijab}

Periode April-Desember 2017

\begin{tabular}{|c|c|c|c|}
\hline \multirow[t]{2}{*}{ Bulan } & \multicolumn{2}{|c|}{ Penjualan } & \multirow[b]{2}{*}{$\begin{array}{c}\text { Pencapaian } \\
\text { Target } \\
(\text { Dalam \%) }\end{array}$} \\
\hline & $\begin{array}{c}\text { Target } \\
\text { (Dalam } \\
\text { Pcs) }\end{array}$ & $\begin{array}{c}\text { Realisasi } \\
\text { (Dalam } \\
\text { Pcs) }\end{array}$ & \\
\hline April & 1.500 & 1.699 & $113,2 \%$ \\
\hline Mei & 1.500 & 2.729 & $181,9 \%$ \\
\hline Juni & 1.500 & 1.528 & $101,8 \%$ \\
\hline Juli & 1.500 & 1.563 & $104,2 \%$ \\
\hline Agustus & 1.500 & 1.626 & $108,4 \%$ \\
\hline September & 1.500 & 1.317 & $87,8 \%$ \\
\hline Oktober & 1.500 & 1.366 & $91 \%$ \\
\hline November & 1.500 & 1.170 & $78 \%$ \\
\hline Desember & 1.500 & 1.487 & $99 \%$ \\
\hline Jumlah & 13.500 & 14.485 & $107,2 \%$ \\
\hline Rata-Rata & 1500 & 1.609 & $107,2 \%$ \\
\hline
\end{tabular}

Sumber: Industri Nanad Hijab (2018) 
Tabel 2. Target dan Realisasi Penjualan Nanad Hijab

Periode Januari-Juli 2018

\begin{tabular}{|c|c|c|c|}
\hline \multirow[t]{2}{*}{ Bulan } & \multicolumn{2}{|c|}{ Penjualan } & \multirow{2}{*}{$\begin{array}{c}\text { Pencapaian } \\
\text { Target } \\
\text { (Dalam \%) }\end{array}$} \\
\hline & $\begin{array}{c}\text { Target } \\
\text { (Dalam } \\
\text { Pcs) }\end{array}$ & $\begin{array}{c}\text { Realisasi } \\
\text { (Dalam } \\
\text { Pcs) }\end{array}$ & \\
\hline Januari & 1.500 & 1.386 & $92,4 \%$ \\
\hline Februari & 1.500 & 1.163 & $77,5 \%$ \\
\hline Maret & 1.500 & 1.370 & $91,3 \%$ \\
\hline April & 1.500 & 1.099 & $73,2 \%$ \\
\hline Mei & 1.500 & 1.480 & $98,6 \%$ \\
\hline Juni & 1.500 & 944 & $62,9 \%$ \\
\hline Juli & 1.500 & 1.202 & $80 \%$ \\
\hline Jumlah & 10.500 & 8.644 & $82,3 \%$ \\
\hline Rata-Rata & 1.500 & 1.235 & $82,3 \%$ \\
\hline
\end{tabular}

Sumber: Industri Nanad Hijab (2018)

Dari keterangan tabel diatas terlihat bahwa pencapaian target tahun 2018 mengalami penurunan disbanding tahun 2017. Penjualan yang sebelumnya telah mencapai target pada periode April Agustus 2017, namun dari bulan Agustus 2017 hingga sampai bulan Juli 2018 belum mencapai target lagi dan cenderung mengalami penurunan. Penjualan tertinggi terjadi pada bulan Mei 2017 dengan penjulan mencapai 2.729 pcs atau rata-rata penjualan sebesar $181,9 \%$, pada bulan Juni 2018 mengalami penurunan yang cukup signifikan yaitu sebesar $62,9 \%$.

\subsection{Tujuan Penelitian}

Tujuan yang ingin dicapai dalam penelitian ini adalah

1. Untuk mengetahui pengaruh produk terhadap keputusan pembelian Busana Muslim di Industri Nanad Hijab Cibinong.

2. Untuk mengetahui pengaruh harga terhadap keputusan pembelian Busana Muslim di Industri Nanad Hijab Cibinong.

3. Untuk mengetahui pengaruh promosi terhadap keputusan pembelian Busana Muslim di Industri Nanad Hijab Cibinong.
4. Untuk mengetahui pengaruh produk, harga, dan promosi secara simultan terhadap keputusan pembelian Busana Muslim di Industri Nanad Hijab Cibinong.

\section{TINJAUAN PUSTAKA}

\subsection{Bauran Pemasaran}

Dalam menjalankan suatu bisnis, harus memiliki strategi agar dapat mewujudkan tujuan dari perusahaan. Strategi yang dimaksud dalam pemasaran disebut bauran pemasaran yang memiliki peran penting dalam mempengaruhi konsumen agar dapat membeli suatu produk yang ditawarkan oleh perusahaan. Bauran pemasaran (marketing mix) merupakan unsur pemasaran yang saling terkait dan digunakan dengan tepat, sehingga perusahaan dapat mencapai tujuan pemasaran dengan efektif, sekaligus memuaskan kebutuhan dan keinginan konsumen.

\section{Produk (Product)}

Menurut Kotler dan Armstrong (2008:266) menjelaskan bahwa Produk merupakan segala sesuatu yang dapat ditawarkan kepada pasar agar menarik perhatian, akuisisi, penggunaan atau konsumsi yang dapat memuaskan suatu keinginan atau kebutuhan. Produk yang ditawarkan meliputi barang fisik, jasa, orang atau pribadi, tempat, organisasi, dan ide. Jadi produk dapat berupa manfaat tangible maupun intangible yang dapat memuaskan pelanggan yang dapat disampaikan melalui atribut produk seperti:

a. Kualitas Produk

Kualitas produk merupakan kemampuan suatu produk untuk melakukan fungsi-fungsinya. Kemampuan itu meliputi daya tahan, kehandalan, dan atribut lain yang berharga pada produk secara keseluruhan. 
b. Fitur Produk

Fitur merupakan alat persaingan untuk mendeferensiasikan produk yang dihasilkan perusahaan terhadap produk sejenis yang dikeluarkan pesaing.

c. Gaya dan Desain Produk

Gaya semata-mata menjelaskan penampilan produk tertentu. Desain yang baik dapat memberikan kontribusi dalam hal kegunaan produk dan juga penampilannya. Gaya dan desain yang baik menarik perhatian, meningkatkan kinerja produk, dan memberikan keunggulan bersaing dipasar.

\section{Harga (Price)}

Kotler dan Armstrong (2008:58) menjelaskan bahwa harga adalah jumlah yang ditagihkan atas suatu produk atau jasa. Lebih luas lagi, harga adalah jumlah semua nilai yang diberikan oleh pelanggan untuk mendapatkan keuntungan dari memiliki atau menggunakan suatu produk atau jasa.

Menurut Kotler dan Armstrong (2012:278), ada empat indikator harga, yaitu:

a. Keterjangkauan harga.

b. Kesesuaian harga dengan kualitas produk.

c. Daya saing harga.

d. Kesesuaian harga dengan manfaat.

\section{Promosi (Promotion)}

Menurut Suryadi (2011:8) menjelaskan bahwa promosi merupakan serangkaian kegiatan untuk mengkomunikasikan, memberi pengetahuan dan meyakinkan orang tentang suatu produk agar ia mengakui kehebatan produk tersebut, membeli dan memakai produk tersebut, juga mengikat pikiran dan perasaannya dalam suatu wujud loyalitas terhadap produk.

Meskipun secara umum bentuk-bentuk promosi memiliki fungsi yang sama, tetapi bentuk-bentuk tersebut dapat dibedakan berdasarkan tugas-tugas khususnya atau sering disebut bauran promosi (promotion mix), yaitu mencakup:

a. Personal Selling adalah komunikasi langsung (tatap muka) antara penjual dan calon pelanggan untuk memperkenalkan suatu produk dan membentuk pemahaman pelanggan tehadap produk sehingga mereka kemudian akan mencoba dan membelinya.

b. Mass Selling merupakan pendekatan yang menggunakan media komunikasi untuk menyampaikan informasi kepada khalayak ramai dalam satu waktu. Ada dua bentuk utama mass selling, yaitu periklanan dan publisitas.

c. Promosi Penjualan (Sales Promotion) adalah bentuk persuasi langsung melalui penggunaan berbagai insentif yang dapat diatur untuk merangsang pembelian produk dengan segera dan meningkatkan jumlah barang yang dibeli pelanggan.

d. Hubungan Masyarakat (Public Relation) merupakan upaya komunikasi menyeluruh dari suatu perusahaan untuk mempengaruhi persepsi, opini, keyakinan, dan sikap berbagai kelompok terhadap perusahaan tersebut. Dalam hal ini yang dimaksud dengan kelompokkelompok itu adalah mereka yang terlibat, mempunyai kepentingan, dan dapat mempengaruhi kemampuan perusahaan dalam mencapai tujuannya. Kelompok tersebut terdiri atas karyawan dan keluarganya, pemegang saham, pelanggan, khalayak/ orangorang yang tinggal disekitar organisasi, pemasok, perantara, pemerintah, serta media massa.

e. Direct marketing adalah sistem pemasaran yang bersifat interaktif, yang memanfaatkan satu atau beberapa media iklan untuk menimbulkan 
respon yang terukur dan transaksi di sembarang lokasi.

f. Word of Mouth atau komunikasi dari mulut ke mulut merupakan proses komunikasi yang berupa pemberian rekomendasi baik secara individu maupun kelompok terhadap suatu produk atau jasa yang bertujuan untuk memberikan informasi secara personal.

4. Tempat (Place)

Tempat / saluran distribusi disebut juga saluran pemasaran adalah sekelompok organisasi yang saling bergantung dan terlibat dalam proses pembuatan produk atau jasa yang disediakan untuk digunakan atau dikonsumsi (Kotler dan Armstrong, 2008:62).

Dalam pemilihan lokasi dapat dipertimbangkan beberapa hal penting, yaitu:

a. Akses, misalnya lokasi yang mudah dijangkau sarana transportasi umum.

b. Visabilitas, misalnya lokasi yang dapat dilihat dengan jelas dari tepi jalan.

c. Lalu lintas (traffic), dimana ada dua hal yang perlu dipertimbangkan, yaitu: banyaknya orang yang berlalu lalang sehingga dapat mempengaruhi keputusan pembelian, dan kepadatan atau kemacetan lalu lintas yang menjadi hambatan untuk mencapai lokasi tersebut.

d. Tempat parkir yang luas dan aman.

e. Ekspansi, tersedia tempat yang cukup untuk perluasan usaha di kemudian hari.

f. Lingkungan, yaitu daerah sekitar yang mendukung produk/jasa yang ditawarkan.

g. Persaingan, yaitu lokasi pesaing.

h. Peraturan pemerintah.

\subsection{Keputusan Pembelian}

Sebelum melakukan pembelian, seseorang biasanya akan melakukan pengambilan keputusan terlebih dahulu terhadap suatu produk. Proses pengambilan keputusan diawali dengan adanya kebutuhan yang berusaha untuk dipenuhi. Menurut Schiffman dan Kanuk (2008:485) pengambilan keputusan adalah seleksi terhadap dua pilihan alternatif atau lebih.Artinya bahwa seseorang dapat membuat keputusan, harus tersedia beberapa alternatif pilihan. Dalam pemilihan suatu produk terdapat proses keputusan pembelian yang terdiri dari beberapa tahap keputusan, dari awal proses hingga proses terakhir pembelian.

Kotler dan Keller (2009:184) menyatakan bahwa proses keputusan pembelian terdiri dari lima tahap sebagai berikut.

1. Pengenalan Masalah

2. Pencarian Informasi

3. Evaluasi Alternatif

4. Keputusan Pembelian

5. Perilaku Pasca Pembelian.

\subsection{Kerangka Pemikiran}

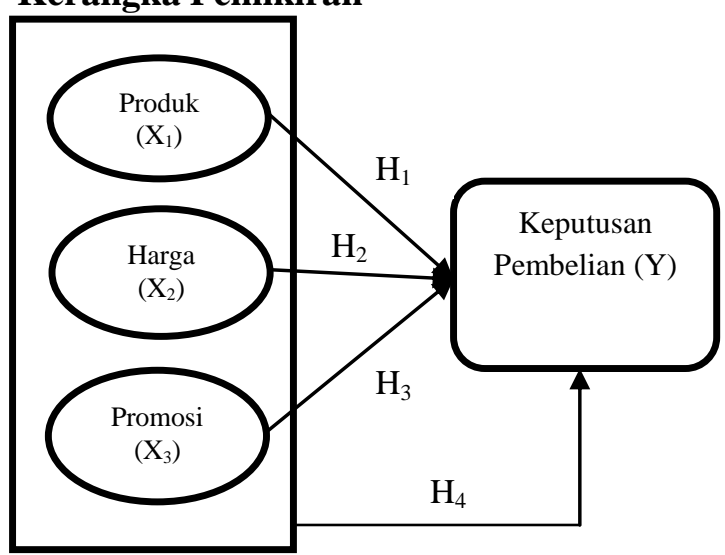

Gambar 1. Kerangka Pemikiran Penelitian

(Sumber : Kotler dan Armstrong, 2008)

\subsection{Hipotesis}

Hipotesis merupakan jawaban sementara atas masalah yang diteliti yang perlu diuji kebenaran lebih lanjut melalui penelitian yang bersangkutan.Berikut ini penulis menguraikan hipotesis penelitian sesuai dengan paradigma keterkaitan variabel penelitian. 
$\mathrm{H}_{0}$ : Tidak ada pengaruh antara produk, harga, dan promosi secara parsial dan simultan terhadap keputusan pembelian busana muslim.

$\mathrm{H}_{1}$ : Ada pengaruh antara variabel produk terhadap keputusan pembelian busana muslim.

$\mathrm{H}_{2}$ : Ada pengaruh antara variabel harga terhadap keputusan pembelian busana muslim.

$\mathrm{H}_{3}$ : Ada pengaruh antara variabel promosi terhadap keputusan pembelian busana muslim.

$\mathrm{H}_{4}$ : Ada pengaruh antara variabel produk, harga, dan promosisecara simultan terhadap keputusan pembelian busana muslim.

\section{METODE PENELITIAN}

Penelitian ini menggunakan metode kuantitatif kausalitas. Populasi dari penelitian ini meliputi konsumen yang membeli produk Nanad Hijab secara online melalui aplikasi Shopee. Dalam penelitian ini teknik pengambilan sampel yang digunakan oleh penulis adalah teknik purposive sampling. Responden penelitian adalah konsumen yang berbelanja minimal satu kali selama 1 (satu) semester terakhir. Jumlah sampel yang akan diambil menggunakan rumus Roscoe (1982:253) dalam Sugiyono (2012:91) Bila dalam penelitian akan melakukan analisis dengan multivariate (korelasi atau regresi ganda), maka jumlah anggota sampel minimal 10 kali variabel yang diteliti. Untuk menghindari terjadinya tingkat kesalahan dalam penelitian ini, peneliti mengambil sampel sebanyak 80 Responden.

Pada penelitian ini variable yang digunakan yaitu:

a. Variabel $\mathrm{X}_{1}$ : Produk

b. Variabel $\mathrm{X}_{2}$ : Harga

c. Variabel $\mathrm{X}_{3}$ : Promosi

d. Variabel Y : Keputusan Pembelian

Metode uji kuesioner menggunakan uji validitas dan uji reliabilitas. Metode uji data menggunakan uji normalitas, uji multikolinieritas dan uji heteroskedastisitas. Teknis analisis data yang digunakan adalah analisis regresi linear berganda. Persamaan regresi yang digunakan dalam penelitian ini adalah:

$$
Y=a+b_{1} X_{1}+b_{2} X_{2}+b_{3} X_{3}+e
$$

dimana :

$$
\begin{aligned}
\mathrm{Y}= & \text { Keputusan pembelian } \\
\mathrm{a}= & \text { Konstanta } \\
\mathrm{b}_{1}-\mathrm{b}_{3}= & \text { Koefisien regresi yang hendak } \\
& \text { ditaksir } \\
\mathrm{X}_{1}= & \text { Produk } \\
\mathrm{X}_{2}= & \text { Harga } \\
\mathrm{X}_{3}= & \text { Promosi } \\
\mathrm{e} & =\text { Standard error }
\end{aligned}
$$

\begin{tabular}{|c|c|c|c|}
\hline Indikator & $\mathrm{r}_{\text {hitung }}$ & $\mathrm{r}_{\text {tabel }}$ & Keterangan \\
\hline \multicolumn{4}{|l|}{ Produk } \\
\hline Pertanyaan 1 & 0,362 & 0,2199 & Valid \\
\hline Pertanyaan 2 & 0,611 & 0,2199 & Valid \\
\hline Pertanyaan 3 & 0,539 & 0,2199 & Valid \\
\hline \multicolumn{4}{|l|}{ Harga } \\
\hline Pertanyaan 4 & 0,369 & 0,2199 & Valid \\
\hline Pertanyaan 5 & 0,534 & 0,2199 & Valid \\
\hline Pertanyaan 6 & 0,391 & 0,2199 & Valid \\
\hline Pertanyaan 7 & 0,55 & 0,2199 & Valid \\
\hline \multicolumn{4}{|l|}{ Promosi } \\
\hline Pertanyaan 8 & 0,493 & 0,2199 & Valid \\
\hline Pertanyaan 9 & 0,619 & 0,2199 & Valid \\
\hline $\begin{array}{l}\text { Pertanyaan } \\
10\end{array}$ & 0,496 & 0,2199 & Valid \\
\hline $\begin{array}{l}\text { Pertanyaan } \\
11\end{array}$ & 0,455 & 0,2199 & Valid \\
\hline $\begin{array}{l}\text { Pertanyaan } \\
12\end{array}$ & 0,641 & 0,2199 & Valid \\
\hline $\begin{array}{l}\text { Pertanyaan } \\
13\end{array}$ & 0,508 & 0,2199 & Valid \\
\hline
\end{tabular}

\section{HASIL DAN PEMBAHASAN}

\subsection{Uji Validitas}

Hasil uji validitas untuk mengetahui validitas pertanyaan kuesioner penelitian. Hasil uji dapat dilihat pada table berikut.

Tabel 3. Hasil Uji Validitas

Sumber: Data diolah 2018 
Berdasarkan hasil uji validitas seperti pada tabel diatas diketahui bahwa nilai koefisien korelasi atau $r_{\text {hitung }}$ untuk semua pertanyaan atau indikator pengukuran variabel memiliki nilai lebih besar dari $r_{\text {tabel }}$ $(0,2199)$. Karena $r_{\text {hitung }}>r_{\text {tabel }}$ maka dalam penelitian ini semua pertanyaan dinyatakan valid.

\subsection{Uji Reliabilitas}

Uji reliabilitas dilakukan untuk melihat kestabilan dan konsistensi dari responden dalam menjawab hal berkaitan dengan pertanyaan yang ada dalam kuesioner. Butir pertanyaan dalam variabel dikatakan reliabel jika nilai cronbach alpha $\geq 0,60$.

Tabel 4. Hasil Uji Reliabilitas Variabel Bauran Pemasaran Indikator Keseluruhan Variabel

Reliability Statistics

\begin{tabular}{|c|c|}
\hline $\begin{array}{l}\text { Cronbach's } \\
\text { Alpha }\end{array}$ & $\mathrm{N}$ of Items \\
\hline .847 & 18 \\
\hline
\end{tabular}

Sumber: Data diolah 2018

Tabel 5. Hasil Uji Reliabilitas Variabel Produk

\begin{tabular}{|r|r|}
\multicolumn{2}{|c|}{ Reliability Statistics } \\
\begin{tabular}{|r|r|}
\hline Cronbach's Alpha & N of Items \\
\hline .646 & \\
\hline
\end{tabular}
\end{tabular}

Sumber: Data diolah 2018

Tabel 6. Hasil Uji Reliabilitas Variabel Harga

\begin{tabular}{|r|r|}
\multicolumn{2}{|c|}{ Reliability Statistics } \\
\hline Cronbach's Alpha & N of Items \\
\hline .599 & \\
\hline
\end{tabular}

Sumber: Data diolah 2018

Tabel 7. Hasil Uji Reliabilitas Variabel Promosi

Reliability Statistics

\begin{tabular}{|r|r|}
\hline Cronbach's Alpha & N of Items \\
\hline .723 & \\
\hline
\end{tabular}

Sumber: Data diolah 2018

\subsection{Uji Normalitas}

Uji normalitas bertujuan untuk mengetahui apakah dalam model regresi, variable-variabel memiliki distribusi normal atau tidak. Deteksi normalitas data dilakukan dengan melihat penyebaran data (titik) pada sumbu diagonal dari grafik (Ghozali, 2011:160). Berikut merupakan hasil uji normalitas:

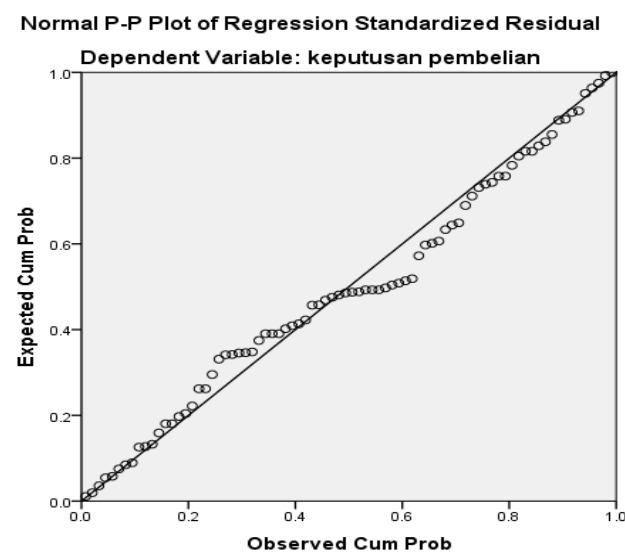

Gambar 2. Hasil Uji Normalitas

Sumber: Data diolah 2018

Berdasarkan gambar diatas menunjukkan data menyebar disekitar garis diagonal dan mengikuti arah garis diagonal, sehingga dapat diketahui bahwa data dalam penelitian ini berdistribusi normal.

\subsection{Uji Heterokedastisitas}

Uji heteroskedastisitas bertujuan untuk menguji apakah dalam model regresi terjadi ketidaksamaan variance dari residual satu pengamatan ke pengamatan lain. Berikut hasil uji heteroskedastisitas dengan menggunakan scatterplot.

Heteroskedastisitas diperkuat dengan menggunakan uji glejser. Dalam menggunakan uji glejser terdapat dasar pengambilan keputusan untuk mengetahui apakah terjadi heteroskedastisitas, yaitu:
1. Sig
0,05
tidak terjadi
heteroskedastisitas.

2. Sig < 0,05 terjadi heteroskedastisitas. 
Tabel 8. Hasil Uji Heterokedastisitas

\begin{tabular}{|c|c|c|c|c|c|c|c|c|}
\hline & \multirow{2}{*}{ Model } & \multicolumn{2}{|c|}{$\begin{array}{l}\text { Unstandardized } \\
\text { Coefficients }\end{array}$} & \multirow{2}{*}{\begin{tabular}{c|}
$\begin{array}{c}\text { Standardized } \\
\text { Coefficients }\end{array}$ \\
Beta
\end{tabular}} & \multirow[b]{2}{*}{ t } & \multirow[b]{2}{*}{ Sig. } & \multicolumn{2}{|c|}{$\begin{array}{c}\text { Collinearity } \\
\text { Statistics }\end{array}$} \\
\hline & & B & $\begin{array}{l}\text { Std. } \\
\text { Error }\end{array}$ & & & & Tolerance & VIF \\
\hline & (Constant) & 2.281 & 2.388 & & 955 & .343 & & \\
\hline & Produk & .480 & .130 & .337 & 3.680 & .000 & .847 & 1.180 \\
\hline & Harga & .348 & .145 & .228 & 2.399 & .019 & .787 & 1.270 \\
\hline & Promosi & .268 & .078 & .328 & 3.438 & .001 & .780 & 1.283 \\
\hline
\end{tabular}

a. Dependent Variable: RES2

Sumber: Data diolah 2018

Berdasarkan tabel di atas diketahui bahwa nilai signifikansi dari variabel Produk, Harga, dan Promosi lebih dari nilai 0,05 . Dengan demikian dapat disimpulkan tidak terjadi heteroskedastisitas.

\subsection{Uji Multikolinieritas}

Menurut Ghozali (2011:105) Uji multikolinieritas bertujuan untuk menguji apakah dalam model regresi ditemukan adanya korelasi antara variabel bebas (independen).

\section{Tabel 9. Hasil Uji Multikolonieritas}

\section{Coefficients $^{\mathrm{a}}$}

\begin{tabular}{|c|c|c|c|c|c|c|c|c|}
\hline & \multirow{2}{*}{ Model } & \multicolumn{2}{|c|}{$\begin{array}{l}\text { Unstandardized } \\
\text { Coefficients }\end{array}$} & \multirow{2}{*}{$\begin{array}{c}\begin{array}{c}\text { Standardized } \\
\text { Coefficients }\end{array} \\
\text { Beta }\end{array}$} & \multirow[b]{2}{*}{$t$} & \multirow[b]{2}{*}{ Sig. } & \multicolumn{2}{|c|}{$\begin{array}{c}\text { Collinearity } \\
\text { Statistics }\end{array}$} \\
\hline & & B & $\begin{array}{l}\text { Std. } \\
\text { Error }\end{array}$ & & & & Tolerance & VIF \\
\hline & (Constant) & 2.281 & 2.388 & & 955 & .343 & & \\
\hline & Produk & .480 & .130 & .337 & 3.680 & .000 & .847 & 1.180 \\
\hline & Harga & .348 & .145 & .228 & 2.399 & .019 & .787 & 1.270 \\
\hline & Promosi & .268 & .078 & .328 & 3.438 & .001 & .780 & 1.283 \\
\hline
\end{tabular}

Sumber: Data diolah 2018

Berdasarkan hasil uji multikolinearitas diatas dapat disimpulkan bahwa ketiga variabel bebas X1 (Produk), X2 (Harga), dan X3 (Promosi)) tidak terjadi multikolinearitas dikarenakan nilai tolerance lebih besar atau $>0,10$ dan nilai VIF nya lebih kecil atau $<10$.

\subsection{Uji Regresi Linier Berganda}

Analisis regresi linear berganda bertujuan untuk mengetahui pengaruh variabel bebas (Produk, Harga, dan Promosi) terhadap variabel terikat (Keputusan Pembelian).
Tabel 10. Hasil Uji Regresi Linier Berganda

\begin{tabular}{|c|c|c|c|c|c|c|}
\hline \multicolumn{7}{|c|}{ Coefficients $^{2}$} \\
\hline & \multirow{2}{*}{ Model } & \multicolumn{2}{|c|}{$\begin{array}{l}\text { Unstandardizad } \\
\text { Coefficients }\end{array}$} & \multirow{2}{*}{\begin{tabular}{|c|}
$\begin{array}{r}\text { Standardized } \\
\text { Coefficients }\end{array}$ \\
Beta \\
\end{tabular}} & \multirow{2}{*}{ T } & \multirow{2}{*}{ Sig. } \\
\hline & & B & $\begin{array}{c}\text { Std. } \\
\text { Error }\end{array}$ & & & \\
\hline \multirow[t]{4}{*}{1} & (Constant) & 2.281 & 2.388 & & .955 & .343 \\
\hline & Produk & .480 & .130 & .337 & 3.680 & .000 \\
\hline & Harga & .348 & .145 & .228 & 2.399 & .019 \\
\hline & Promosi & .268 & .078 & .328 & 3.438 & .001 \\
\hline
\end{tabular}

Sumber: Data diolah 2018

Dari hasil analisis data pada tabel tersebut, dapat diketahui persamaan regresinya, yaitu:

$$
Y=2,281+0,480 X_{1}+0,348 X_{2}+0,268 X_{3}
$$

1. Konstanta sebesar 2,281 mempunyai arti bahwa jika variabel Produk, Harga, dan Promosi dianggap konstan maka tingkat keputusan konsumen untuk membeli online busana muslim di Industri Nanad Hijab sebesar 2,281.

2. Variabel Produk $\left(\mathrm{X}_{1}\right)$ mempunyai koefisien sebesar 0,480 yang berarti apabila produk meningkat sebesar 1 satuan dengan menganggap variabel bebas lainnya tetap, maka akan dapat meningkatkan keputusan konsumen untuk membeli online busana muslim di Industri Nanad Hijab sebesar 0,480.

3. Variabel Harga $\left(\mathrm{X}_{2}\right)$ mempunyai koefisien sebesar 0,348 yang berarti apabila harga meningkat sebesar 1 satuan dengan menganggap variabel bebas lainnya tetap, maka akan dapat meningkatkan keputusan konsumen untuk membeli online busana muslim di Industri Nanad Hijab sebesar 0,348.

4. Variabel Promosi $\left(\mathrm{X}_{3}\right)$ mempunyai koefisien sebesar 0,268 yang berarti apabila promosi meningkat sebesar 1 satuan dengan menganggap variabel bebas lainnya tetap, maka akan dapat meningkatkan keputusan konsumen untuk membeli online busana muslim di Industri Nanad Hijab sebesar 0,268. 


\subsection{Uji Hipotesis}

\subsubsection{Uji t}

Tabel 11. Hasil Hipotesis dengan Uji t

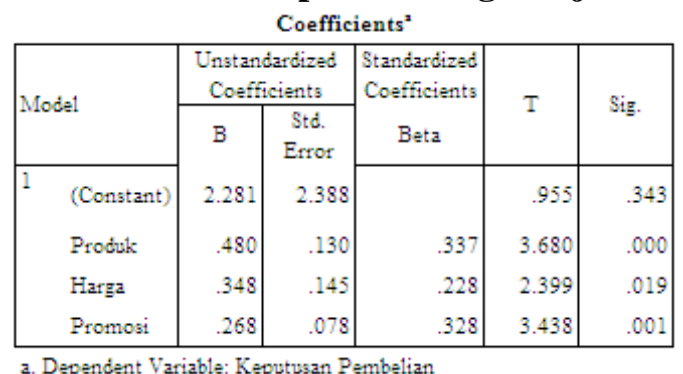

Sumber: Data diolah 2018

Berikut ini akan dijelaskan analisa masing-masing variabel:

1. Diketahui nilai signifikansi untuk variabel Produk $\left(\mathrm{X}_{1}\right)$ adalah sebesar $0,000<0,05$ dan nilai $t_{\text {hitung }}(3,680)>t$ table $(1,991)$, maka dinyatakan $\mathrm{H}_{\mathrm{o}}$ ditolak dan $\mathrm{H}_{1}$ diterima. Sehingga dapat disimpulkan terdapat pengaruh signifikan antara variabel Produk $\left(\mathrm{X}_{1}\right)$ terhadap keputusan pembelian online busana muslim di Industri Nanad Hijab.

2. Diketahui nilai signifikansi untuk variabel Harga $\left(\mathrm{X}_{2}\right)$ adalah sebesar $0,019<0,05$ dan $t_{\text {hitung }}(2,399)>t_{\text {tabel }}$ (1,991), maka dinyatakan $\mathrm{H}_{\mathrm{o}}$ ditolak dan $\mathrm{H}_{2}$ diterima. Sehingga dapat disimpulkan terdapat pengaruh signifikan antara variabel Harga $\left(\mathrm{X}_{2}\right)$ terhadap keputusan pembelian online busana muslim di Industri Nanad Hijab.

3. Diketahui nilai signifikansi untuk variabel Promosi $\left(\mathrm{X}_{3}\right)$ adalah sebesar $0,001<0,05$ dan $\mathrm{t}_{\text {hitung }}(3,438)>\mathrm{t}_{\text {tabel }}$ (1,991), maka $\mathrm{H}_{\mathrm{o}}$ ditolak dan $\mathrm{H}_{3}$ diterima. Sehingga dapat disimpulkan terdapat pengaruh signifikan antara variabel Promosi $\left(\mathrm{X}_{3}\right)$ terhadap keputusan pembelian online busana muslim di Industri Nanad Hijab.
4.7.2 Uji F

Tabel 12. Hasil Hipotesis Uji F

\begin{tabular}{|c|c|c|c|c|c|}
\hline \multicolumn{6}{|c|}{ ANOVA } \\
\hline Model & $\begin{array}{l}\text { Sum of } \\
\text { Squares }\end{array}$ & df & $\begin{array}{l}\text { Mean } \\
\text { Square }\end{array}$ & $\mathrm{F}$ & Sig. \\
\hline 1 Regression & 115.592 & 3 & 38.531 & 21.564 & $.000^{\mathrm{b}}$ \\
\hline Residual & 135.796 & 76 & 1.787 & & \\
\hline Total & 251.388 & 79 & & & \\
\hline
\end{tabular}

Sumber: Data diolah 2018

Berdasarkan hasil data diatas diketahui nilai p-value (signifikasi) 0,000 lebih kecil dari 0,05 . Nilai $F_{\text {hitung }}(21,564)>F_{\text {tabel }}$ $(2,72)$, maka dinyatakan $\mathrm{H}_{\mathrm{o}}$ ditolak dan $\mathrm{H}_{4}$ diterima. Sehingga dapat disimpulkan bahwa terdapat pengaruh antara Produk $\left(\mathrm{X}_{1}\right)$, Harga $\left(\mathrm{X}_{2}\right)$, dan Promosi $\left(\mathrm{X}_{3}\right)$ secara bersama-sama (simultan) terhadap keputusan pembelian online busana muslim di Industri Nanad Hijab Cibinong.

\subsection{Uji Koefisien Determinasi}

Uji koefisien determinasi $\left(\mathrm{R}^{2}\right)$ bertujuan untuk mengukur seberapa jauh kemampuan model dalam menerangkan variasi variabel dependen.

Tabel 13. Hasil Uji Koefisien Determinasi

\begin{tabular}{|c|c|c|c|c|}
\hline \multicolumn{5}{|c|}{ Model Summary } \\
\hline Model & $\mathrm{R}$ & R Square & $\begin{array}{l}\text { Adjusted } \\
\text { R Square }\end{array}$ & $\begin{array}{l}\text { Std. Error of } \\
\text { the Estimate }\end{array}$ \\
\hline 1 & $.678^{\mathrm{a}}$ & .460 & .438 & 1.33671 \\
\hline
\end{tabular}

Sumber: Data diolah 2018

Berdasarkan hasil uji koefisien determinasi diatas diperoleh nilai Adjusted $R$ square sebesar 0,438 atau $43,8 \%$. Hal ini mengandung arti bahwa variabel Produk, Harga, dan Promosi mampu menjelaskan atau mempengaruhi variabel dependen keputusan pembelian sebesar 43,8\%. Sedangkan $56,2 \%$ lainnya dipengaruhi oleh 
variabel lain yang tidak diteliti dalam penelitian ini.

(Sumber : Kotler dan Armstrong, 2008)

\section{KESIMPULAN DAN SARAN}

\subsection{Kesimpulan}

Berdasarkan hasil analisis data dan pembahasan dapat ditarik kesimpulan sebagai berikut:

1. Produk penjualan mempunyai pengaruh terhadap keputusan pembelian dengan nilai koefisien sebesar $48,0 \%$.

2. Harga penjualan mempunyai pengaruh terhadap keputusan pembelian dengan nilai koefisien sebesar $34,8 \%$.

3. Promosi penjualan mempunyai pengaruh terhadap keputusan pembelian dengan nilai koefisien sebesar 26,8\%.

4. Variabel Produk, Harga, Promosi bersama-sama berpengaruh terhadap keputusan pembelian online di Industri Nanad Hijab dibuktikan dengan nilai signifikasi 0,000 jauh lebih kecil dari 0,05 dan nilai $F_{\text {hitung }} 21,564$ lebih besar dari $\mathrm{F}_{\text {tabel }} 2,72$.

\subsection{Saran}

Berdasarkan hasil kesimpulan diatas, maka saran yang dapat diberikan penulis adalah sebagai berikut:

1. Sebagai pihak manajemen dan pengelola hendaknya mempertahankan kualitas produk yang bermutu, dan meningkatkan desain produk. Hal ini dilakukan agar produk tidak ketinggalan zaman serta mengikuti tren yang dikehendaki masyarakat, karena semakin baik kualitas dan desain produk akan meningkatkan minat beli konsumen.

2. Pihak manajemen dan pengelola hendaknya mempertahankan harga yang sesuai kebutuhan dengan kualitas produk yang bagus.
3. Pihak manajemen dan pengelola hendaknya lebih sering melakukan promosi di media sosial dan mengikuti bazar di beberapa tempat agar konsumen mengetahui dan lebih mengenal produk Nanad Hijab.

\section{DAFTAR PUSTAKA}

Assauri, Sofjan. 2013. Manajemen Pemasaran. Jakarta: Rajawali Pers.

Ghozali, Imam. 2011. Aplikasi Multivariate Dengan Program SPSS. Semarang: Universitas Dipenogoro.

Hurriyati, Ratih. 2015. Bauran Pemasaran dan Loyalitas Konsumen. Bandung: Alfabeta CV.

Indahsari, Nita Diah. 2017. Pengaruh Bauran Pemasaran Terhadap Minat Beli Pengunjung Pada Griya Busana Raffisya. Surabaya: Jurnal Ilmu dan Riset Manajemen. Vol. 6, No.7.

Kotler, Philip \& Kevin Lane Keller.2009. Manajemen Pemasaran, Jilid 1, edisi 13. Jakarta: Erlangga.

Saladin, Djaslim. 2004. Manajemen Pemasaran (Analisis, Perencanaan, Pelaksanaan, dan Pengendalian). Bandung: Linda Karya.

Sugiyono. 2014. Metode Penelitian Bisnis (Pendekatan Kuantitatif, Kualitatif, dan R\&D). Bandung: Alfabeta CV.

Tjiptono, Fandy. 2015. Strategi Pemasaran. Edisi keempat. CV. Andi Offset. Yogyakarta.

Pertiwi, Marina Intan, Edi Yulianto, Sunarti. Pengaruh Bauran Pemasaran Terhadap Keputusan Pembelian (Survei Pada Konsumen Baker's King Donnuts \& Coffe di MX Mall Malang). Malang: Jurnal Administrasi Bisnis. Vol. 37 No.1.

Utami, Puspa Arum. Pengaruh Bauran Pemasaran Terhadap Keputusan Pembelian Konsumen Di Minimarket KOPMA Universitas Negeri

Yogyakarta.Ekonomi. Fakultas 
Ekonomi. Universitas Negeri

Yogyakarta.

https://blogunik.com/trend-busana-wanita-

muslim-2018/ diakses 12 Juli 2018. 